\title{
Pesticide residues in bee products collected from cherry trees protected during blooming period with contact and systemic fungicides
}

\author{
Marek Kubik ${ }^{\mathrm{a} *}$, Janusz Nowacki ${ }^{\mathrm{a}}$, Andrzej Pidek ${ }^{\mathrm{a}}$, \\ Zofia Warakomska ${ }^{b}$, Lech Michalczuk ${ }^{\mathrm{a}}$, WXodzimierz Goszczyñski ${ }^{\mathrm{a}}$ \\ ${ }^{a}$ Institute of Pomology and Floriculture, 96-100 Skierniewice, Pomologiczna 18, Poland \\ ${ }^{\mathrm{b}}$ University of Agriculture, Department of Botany, 20-950 Lublin, Poland
}

(Received 23 November 1998; revised 27 April 1999; accepted 7 June 1999)

\begin{abstract}
Pesticide (vinclozolin, iprodione and methyl tiophanate) residues were determined in honey, pollen and bee bread from a plantation of cherry (Prunus cerasus) $\mathrm{cv}$. English morello. The least contaminated were honey samples, which contained up to $0.1 \mathrm{mg} \cdot \mathrm{kg}^{-1}$ and pollen with up to $0.25 \mathrm{mg} \cdot \mathrm{kg}^{-1}$, and the most contaminated was bee bread with up to $23.6 \mathrm{mg} \cdot \mathrm{kg}^{-1}$ of the used fungicides. Obtained results suggest that residues of vinclozolin and iprodione present in pollen grains are chemically modified (possibly conjugated) and thus undetected by the method used. During fermentation of bee bread the conjugates are hydrolysed and free pesticides released. Experiments showed that both vinclozolin and iprodione applied to old leaves were transported to young leaves and flowers. Thus, despite contact mode of action declared by producers, they also show systemic properties. This assumption may be corroborated by the dynamics of pollen contamination (4-5 days of lag period between the spray time and time of incidence of maximum contamination). $($ Inra/DIB/ AGIB/Elsevier, Paris
\end{abstract}

honey / pollen / contamination / residues / fungicides

\section{INTRODUCTION}

Systemic pesticides are transported in the plant vascular system together with assimilates and other nutrients. Since anthers and nectaries are active physiological sinks, there is a possibility of accumulation of those chemicals in pollen grains and nectar collected by bees. It was observed that nectar collected from plants sprayed with systemic insecticides can be toxic for bees for several days after treatment $[1,3,7,8]$. Fungi-

\footnotetext{
* Correspondence and reprints

E-mail: mkubik@insad.isk.skierniewice.pl
} 
cides have relatively low toxicity for bees, thus spraying of blooming plantations is allowed and the prevention time (time elapsed from spraying to safe bee operation on the flowers) for most preparations is short - about $1 \mathrm{~h}$. However, even though fungicides may not affect bees, residues can be found in bee products - pollen and nectar - collected by bees from protected plants.

It was previously shown [6] that a systemic fungicide - methyl tiophanate - penetrates into the nectar of black currant about eight times more effectively than contact acaricide - endosulfan. Black currant flowers were an attractive source of nectar, but their pollen was almost totally neglected by bees.

Bees frequently visit cherry flowers and both pollen and nectar are readily collected. Cherries are sprayed with fungicides during the blooming period, and thus are an excellent model for studying contamination of bee products. Daily harvest of pollen allows changes in concentration of toxic substances with time to be followed, thus obtaining a dynamic picture of contamination of pollen grains.

The aim of this work was to investigate the hypothesis that systemic fungicides more readily penetrate into bee products than contact ones, which may cause greater risk for consumers.

\section{MATERIALS AND METHODS}

\subsection{Preparation of bees and plantation}

Five bee colonies in good condition and of equal strength were placed in the middle of a 4.5 hectare cherry cv. English morello plantation just before opening of the first flowers. Before moving, the bees were transferred into hives containing only empty combs and foundations. The queens were confined on a single comb.

The plantation was sprayed twice: the first treatment with a mixture of Topsin $M$ $\left(1.0 \mathrm{~kg} \cdot \mathrm{ha}^{-1}\right)$, active ingredient: methyl tio- phanate, and Rovral $50 \mathrm{WP}\left(1.5 \mathrm{~kg} \cdot \mathrm{ha}^{-1}\right)$, active ingredient: iprodione, was given before breaking of buds, and the second, with a mixture of Topsin M (1.0 kg.ha $\left.{ }^{-1}\right)$, Rovral 50 WP $\left(0.375 \mathrm{~kg} \cdot \mathrm{ha}^{-1}\right)$ and Ronilan 50 WP $\left(0.75 \mathrm{~kg} \cdot \mathrm{ha}^{-1}\right)$, active ingredient: vinclozolin, 6 days later, when the trees were in a full bloom.

\subsection{Collecting samples}

The hives were equipped with pollen traps and pollen was harvested daily. After the end of the experiment the honey was extracted and all bee bread carefully scraped out. All bee products were stored in a freezer at $20^{\circ} \mathrm{C}$, but part of the honey after the post-harvest analysis was stored in darkness at room temperature and pesticide determinations were repeated after 4 , 6 and 12 months.

\subsection{Transport of vinclozolin and iprodione in cherry shoots}

Twenty-one shoots of cherry just before flower bud breaking were selected for the experiment. The upper half of the shoots was carefully covered with polyethylene foil for protection against contamination with fungicides, and the leaves at the bottom part of the shoots were painted with a mixture of vinclozolin and iprodione using a small, soft brush. After 5 days the shoots were cut off and the pesticide residues were determined in lower (painted) and upper (unpainted) leaves and flowers.

\subsection{Extraction of fungicides}

For accurate determination of residue levels in bee products, three kinds of samples of each bee product were examined. Unsprayed and fungicide-free, fortified unsprayed fungicide-free, and experimental contaminated samples of honey, pollen and bee bread.

\subsubsection{Extraction of methyl tiophanate}

\subsubsection{Honey}

Honey $(20 \mathrm{~g})$ was dissolved in $10 \mathrm{~mL}$ of water, $\mathrm{pH}$ was adjusted to $6-7$ and the solution was filtered through Millipore $60 \mu \mathrm{m}$ filter. 


\subsubsection{Pollen and bee bread}

Pollen $(1 \mathrm{~g})$ or bee bread was mixed with $10 \mathrm{~mL}$ of $0.01 \mathrm{~N} \mathrm{HCl}$. The mixture was stirred with a magnetic stirrer for $1 \mathrm{~h}, \mathrm{pH}$ was adjusted to 6-7 and the solution was filtered through a porous glass filter.

\subsubsection{Extraction of vinclozolin and iprodione}

\subsubsection{Honey}

Honey ( $20 \mathrm{~g}$ ) was dissolved in $20 \mathrm{~mL}$ of distilled water and shaken vigorously for $1 \mathrm{~h}$. Acetone $(20 \mathrm{~mL})$ and ammonium sulphate $(5 \mathrm{~g})$ were then added and shaking was continued for $30 \mathrm{~min}$. Then the solution was refrigerated for several hours. The upper, organic phase was collected, acetone was evaporated under reduced pressure, the residue was dissolved in $50 \mathrm{~mL}$ of distilled water and later purified as described below.

\subsubsection{Pollen and bee bread}

Pollen or bee bread ( $5 \mathrm{~g}$ ) was shaken with $30 \mathrm{~mL}$ of acetone for $30 \mathrm{~min}$ and filtered. Distilled water $(10 \mathrm{~mL})$ was added to the filtrate and acetone evaporated under reduced pressure. The residue was dissolved in $50 \mathrm{~mL}$ of distilled water.

Pollen pellets for determination of pesticide residue were hand-separated to contain only cherry pollen. For bee bread such separation was impossible; thus, for comparison of contamination the data for bee bread should be multiplied by a factor of 2 (because bee bread consists of approximately $50 \%$ of cherry pollen-table II).

\subsubsection{Flowers and leaves}

Leaves or flowers $(20 \mathrm{~g})$ were homogenised with $50 \mathrm{~mL}$ of acetone, left for several hours at room temperature and filtered through filter paper. The acetone was then evaporated under reduced pressure, the residue filtered and dissolved in $50 \mathrm{~mL}$ with water.

\subsection{Purification of fungicides}

\subsubsection{Purification of methyl tiophanate and conversion to carbendazime}

Clear water solution (obtained as above) was passed slowly through a Bakerbond spe SDB-1 disposable column (Baker). The column was rinsed twice with $6 \mathrm{~mL}$ of water followed by $20 \mathrm{~mL}$ of $50 \%$ methanol, dried with a stream of dry air and eluted with $7 \mathrm{~mL}$ of methyl alcohol. The eluate was mixed with $2 \mathrm{~mL}$ of concentrated acetic acid and methanol was evaporated under reduced pressure. Then, $100 \mathrm{mg}$ of copper acetate and $10 \mathrm{~mL}$ of $50 \%$ acetic acid were added and the mixture was boiled under reflux for $30 \mathrm{~min}$. After cooling, the reaction mixture was extracted twice with $10 \mathrm{~mL}$ of chloroform and the chloroform extract was discarded. The water phase was neutralised to $\mathrm{pH}$ 6-7 with $3 \mathrm{M} \mathrm{NaOH}$ and extracted twice with $40 \mathrm{~mL}$ of chloroform. Chloroform extracts were combined, dried over anhydrous sodium sulphate, filtered and evaporated to dryness under reduced pressure. Dry residue was dissolved in $1 \mathrm{~mL}$ of methyl alcohol and $10 \mu \mathrm{L}$ of this solution was analysed by HPLC.

\subsubsection{Purification of vinclozolin and iprodione}

Water solutions of vinclozolin and iprodione samples, prepared as above, were passed slowly through Spe-500 disposable extraction column. The column was then rinsed with $6 \mathrm{~mL}$ of water and dried with a stream of air. The vinclozolin and iprodione were eluted with $6 \mathrm{~mL}$ of toluene followed by $2 \times 3 \mathrm{~mL}$ of acetone. The eluates were combined, evaporated to dryness and dry residue dissolved in $1 \mathrm{~mL}$ of toluene. Samples of this solution $(1 \mu \mathrm{L})$ were taken for analysis by GLC.

\subsection{Determination of recovery rate of fungicides}

\subsubsection{Recovery of methyl tiophanate}

\subsubsection{Honey}

Standard solution $(1 \mu \mathrm{L})$ in methanol containing $5 \mu \mathrm{g}$ of methyl tiophanate (Promochem, $98 \%$ of purity) was added to $20 \mathrm{~g}$ of honey and the sample was processed as described in sections 2.4.1.1. and 2.4.1.7. The recovery of methyl tiophanate was $87.5 \pm 9.2 \%$.

\subsubsection{Pollen and bee bread}

Acetone solution $(10 \mathrm{~mL})$ containing $5 \mu \mathrm{g}$ of methyl tiophanate was added to $1 \mathrm{~g}$ of pollen or bee bread. The solvent was evaporated under reduced pressure using rotary evaporator and the whole procedure of extraction and purification accordingly to sections 2.4 .1 .2 . and 2.5.1. was 
performed. It was found that the recovery of methyl tiophanate was $78.9 \pm 10.7 \%$.

\subsubsection{Recovery of vinclozolin and iprodione}

\subsubsection{Honey}

Vinclozolin and iprodione standards $(1 \mu \mathrm{g})$ (Promochem) in $1 \mathrm{~mL}$ of acetone were each added to an empty $100 \mathrm{~mL}$ flask, the solvent was evaporated under reduced pressure using rotary evaporator, $20 \mathrm{~g}$ of honey dissolved in $20 \mathrm{~mL}$ of distilled water were added and shaken vigorously for $1 \mathrm{~h}$. Then, the procedure of extraction and purification of fungicides was performed according to sections 2.4.2.1,2.5.2 and 2.7.2. The recovery of vinclozolin and iprodione was established as $81.5 \pm 5.6$ and $77.3 \pm 3.2 \%$, respectively.

\subsubsection{Pollen and bee bread}

Vinclozolin and iprodione standards $(3 \mu \mathrm{g})$ (Promochem) in $1 \mathrm{~mL}$ of acetone were each added to $5 \mathrm{~g}$ of pollen pellets or bee bread suspended in $30 \mathrm{~mL}$ acetone. The acetone was evaporated under reduced pressure and further purification and determination were performed as described in sections 2.4.2.2, 2.5.2. and 2.7.2. The recovery determined this way was $80.4 \pm$ 1.8 for vinclozolin and $78.2 \pm 4.3 \%$ for iprodione, respectively.

\subsubsection{Leaves and flowers}

Standards of vinclozolin and iprodione (Promochem), $1 \mu \mathrm{g}$ of each dissolved in $1 \mathrm{~mL}$ of acetone, were added to mixture containing $20 \mathrm{~g}$ of leaves or flowers taken from unsprayed, control cherry trees. Further analysis accordingly to procedures described in sections 2.4.2.3, 2.5.2 and 2.7.2 was performed. The recovery of vinclozolin and iprodione was $78.6 \pm 4$ and $79.4 \pm 6.8 \%$, respectively.

\subsection{Quantification of fungicides}

\subsubsection{Methyl tiophanate}

Analysis of carbendazim - the product of cyclisation of methyl tiophanate - was performed using a Hewlett-Packard Series 1050 liquid chromatograph equipped with Supelcosil LC-18-DB column, $25 \mathrm{~cm} \times 4.6 \mathrm{~mm}$, and UV detector $(280 \mathrm{~nm})$. Elution was performed with $0.01 \mathrm{M}$ $\mathrm{K}_{2} \mathrm{HPO}_{4}$ solution at a flow rate of $0.8 \mathrm{~mL} \cdot \mathrm{min}^{-1}$.
The retention time for carbendazim in these conditions was $8.77 \mathrm{~min}$. Each analysis was performed at least twice, and each chromatographic measurement was repeated two to three times. The recovery, determined on fortified samples was $87.5 \pm 9.2 \%$. The limit of detection of methyl tiophanate was 0.01 and $0.1 \mathrm{mg} \cdot \mathrm{kg}^{-1}$ in honey and pollen and bee bread, respectively.

\subsubsection{Vinclozolin and iprodione}

Samples of toluene solutions ( $1 \mu \mathrm{L})$ were injected onto a gas chromatograph HP 5890 series (Hewlett-Packard) equipped with capillary column HP-5, $30 \mathrm{~m} \times 0.32 \mathrm{~mm}$, film thickness $0.25 \mu \mathrm{m}$ and ECD detector. The carrier gas was helium $\left(3 \mathrm{~mL} \cdot \mathrm{min}^{-1}\right)$, the makeup gas nitrogen $\left(60 \mathrm{~mL} \cdot \mathrm{min}^{-1}\right)$, the injector temperature $240{ }^{\circ} \mathrm{C}$ and the detector temperature $300^{\circ} \mathrm{C}$. The initial temperature of the oven was maintained at $120^{\circ} \mathrm{C}$ by $1 \mathrm{~min}$ then increased at a rate of $30^{\circ} \mathrm{C} \cdot \mathrm{min}^{-1}$ to $280^{\circ} \mathrm{C}$ and after $8 \mathrm{~min}$ increased again at a rate of $40^{\circ} \mathrm{C} \cdot \mathrm{min}^{-1}$ to $280^{\circ} \mathrm{C}$ and was maintained at this level for $1 \mathrm{~min}$. Retention times for vinclozolin and iprodione under those conditions were 6.190 and $11.015 \mathrm{~min}$, respectively. The limits of detection of vinclozolin and iprodione were 0.001 and $0.0025 \mathrm{mg} \cdot \mathrm{kg}^{-1}$ for honey, 0.0004 and $0.01 \mathrm{mg} \cdot \mathrm{kg}^{-1}$ for pollen and bee bread and 0.0001 and $0.0025 \mathrm{mg} \cdot \mathrm{kg}^{-1}$ for leaves and flowers, respectively.

\subsection{Pollen analysis}

\subsubsection{Identification of pellets}

Pollen pellets were segregated according to their shape and colour in white and UV (with Wood's filter for identification of fluorescing pellets) light. For species identification, several of such separated pellets were taken, moistened with a drop of water and examined under the microscope with $100 \times$ magnification.

\subsubsection{Identification of pollen in individual pellets and bee bread}

A sample of $4 \mathrm{~g}$ of pellets or bee bread was suspended in $10 \mathrm{~mL}$ of distilled water alkalised with diluted $\mathrm{NaOH}$ solution to $\mathrm{pH}$ 9.0. After some time swollen pollen grains were examined under the microscope with $100 \times$ magnification and compared with pollen of known origin. Only cherry pellets were separated for pesticide residues determination. 


\subsubsection{Identification of pollen in honey}

Honey $(10 \mathrm{~g})$ was diluted with $20 \mathrm{~mL}$ of warm $\left(50^{\circ} \mathrm{C}\right)$ distilled water and the solution was centrifuged at $3000 \mathrm{rpm}$ for $5 \mathrm{~min}$. The pellet was collected, carefully mixed with a small amount of water and examined under microscope.

\section{RESULTS}

Tables $I$ and $I I$ and figure $I$ depict residues of methyl tiophanate, vinclozolin and iprodione in honey, bee bread and pollen, respectively. Average data are presented in table III. As can be seen, contamination of honey $\left(0.0589,0.107\right.$ and $\left.0.0231 \mathrm{mg} \cdot \mathrm{kg}^{-1}\right)$ is the lowest, but for bee bread quantities of residues are much greater, approximately $1.929,23.6$ and $3.055 \mathrm{mg} \cdot \mathrm{kg}^{-1}$ for methyl tiophanate, vinclozolin and iprodione, respectively. It is strange that residues of fungicides in pollen pellets $(0.25,0.12$ and $0.009 \mathrm{mg} \cdot \mathrm{kg}^{-1}$ for methyl tiophanate, vinclozolin and iprodione, respectively) are much lower than residues in bee bread, especially for iprodione (above 300 times) and vinclozolin (about 200 times), though cherry pollen is the main component of bee bread (table II).

Although the level of contamination of honey and bee bread varied in individual colonies (tables $I$ and $I I$ ), in each colony it was proportional to the proportion of cherry nectar in the honey and cherry pollen in the bee bread. That means that all the cherry nectar and cherry pollen gathered by bees originated from sprayed trees. In the case of black currant bushes [6], and for apple trees (unpublished results) such relationships were not observed. That means that part of the black currant and apple nectar and apple pollen also originated from unsprayed plants of black currant and apple orchards located in the vicinity of the experimental plantations.

Cherry flowers produce abundant pollen [9], which is willingly collected by bees. Pollen traps revealed that harvested pollen consisted on average of $53.8 \%$ of cherry pellets (table IV). Similar $(49.9 \%$ ) was the average portion of cherry pollen in bee bread (table II).

Figure I presents contamination of pollen collected daily with the pollen traps. The first spraying of the plantation with a mixture of methyl tiophanate $\left(0.7 \mathrm{~kg} \cdot \mathrm{ha}^{-1}\right)$ and iprodione, also $0.7 \mathrm{~kg} \cdot \mathrm{ha}^{-1}$, was performed on 29 April, just before flowers bud breaking. Despite the fact that the flowers were closed at that time, pollen collected 3 days later was significantly (about $5 \mathrm{mg} \cdot \mathrm{kg}^{-1}$ ) contaminated with methyl tiophanate. The level of pollen contamination with iprodione was substantially lower (about $0.3 \mathrm{mg} \cdot \mathrm{kg}^{-1}$ ). After the second spray (5 May) with a mixture of methyl tiophanate $\left(0.7 \mathrm{~kg} \cdot \mathrm{ha}^{-1}\right)$ iprodione $\left(0.185 \mathrm{~kg} \cdot \mathrm{ha}^{-1}\right)$ and vinclozolin $\left(0.375 \mathrm{~kg} \cdot \mathrm{ha}^{-1}\right)$, the maximum of contamination of cherry pollen was observed after a lag period of 4 days for methyl tiophanate and vinclozolin and 5 days for iprodione. The maximal contamination with methyl tiophanate was of the same magnitude as previously (above $4 \mathrm{mg} \cdot \mathrm{kg}^{-1}$ ). It seems somewhat strange that there was no increase in residues immediately (next day) after the second spraying.

To maintain the same conditions of application for different fungicides, the mixture of preparations was used. But amounts of chemicals in the mixture were different and were necessitated by the protection programme. So for further calculation of the ability of particular fungicides to penetrate into bee products / recalculated residue $\left.\left(\mathrm{mg} \cdot \mathrm{kg}^{-1}\right)_{\mathrm{M}}\right]$ was used. On the basis of actual measured amount of given fungicide in each bee product, taking into account that uptake of pesticides is concentration-dependent, there was a recalculated hypothetical contamination of this product as if one mole of each active substance per hectare was applied. For further characterisation of the ability of a given fungicide for contamination of all bee products, the ratio of recalculated residues of systemic to contact active 


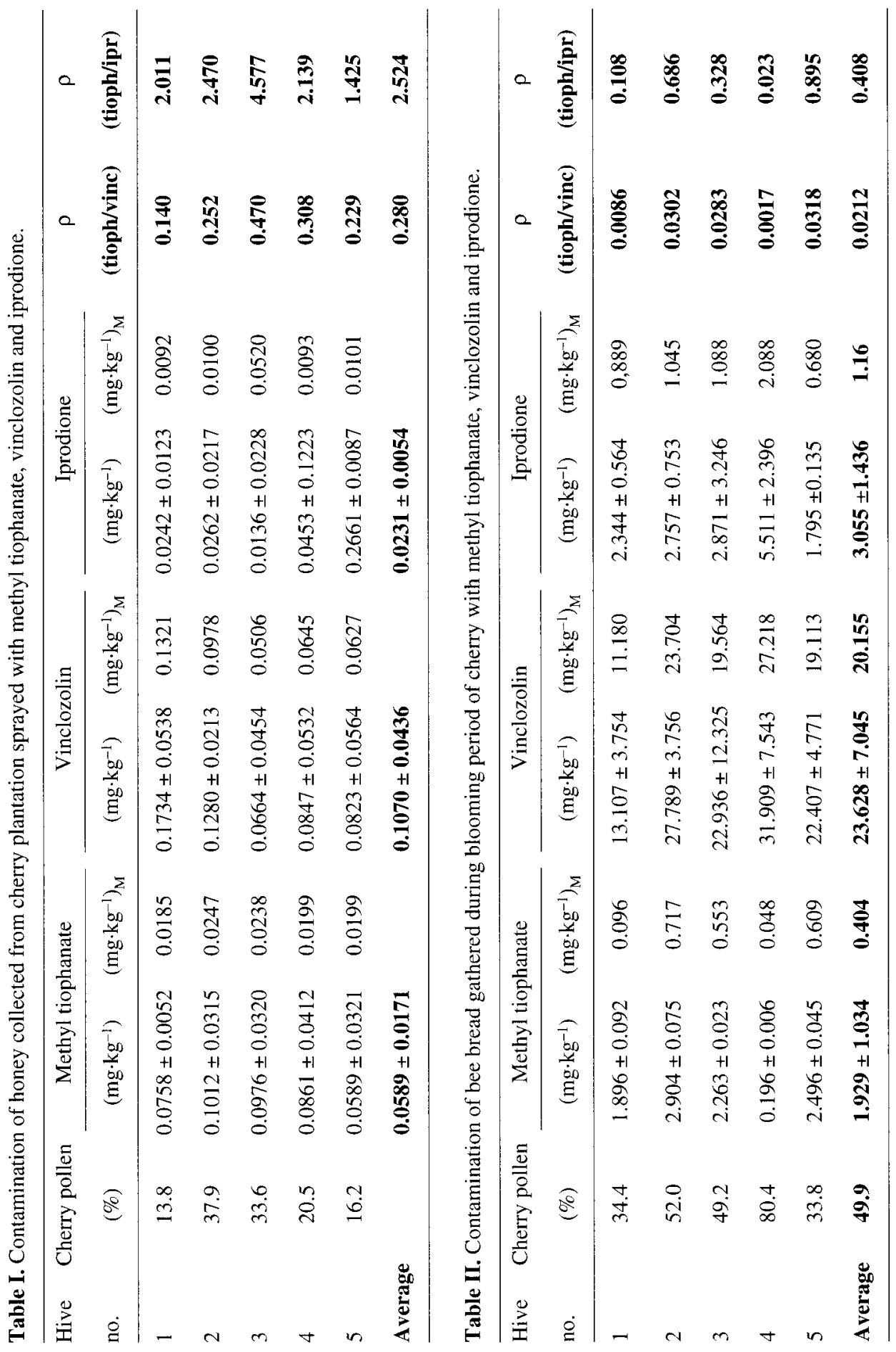




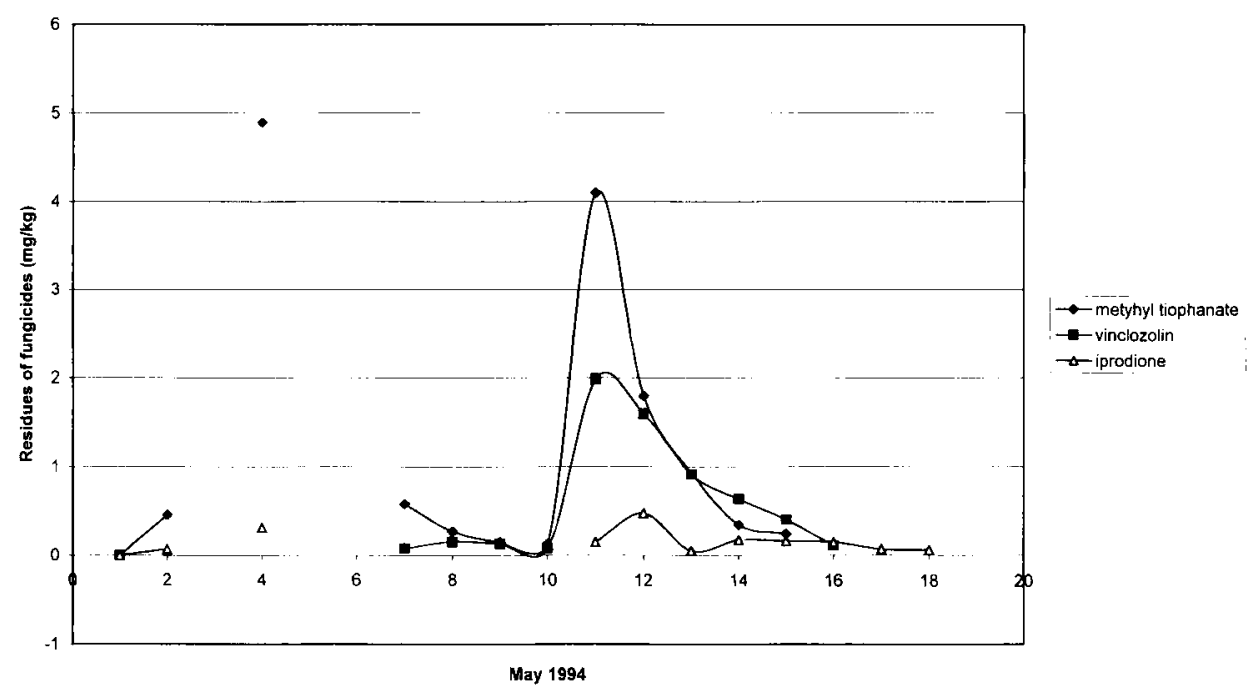

Figure 1. Daily contamination of cherry pollen with fungicides.

Table III. Average residue of methyl tiophanate, vinclozolin and iprodione in bee products.

\begin{tabular}{lcccccccc}
\hline Product & \multicolumn{2}{c}{ Methyl tiophanate } & & \multicolumn{2}{c}{ Vinclozolin } & & \multicolumn{2}{c}{ Iprodione } \\
\cline { 2 - 3 } & $\left(\mathrm{mg} \cdot \mathrm{kg}^{-1}\right)$ & $\begin{array}{c}\text { Ratio (bee } \\
\text { bread/pollen })\end{array}$ & $\left(\mathrm{mg} \cdot \mathrm{kg}^{-1}\right)$ & $\begin{array}{c}\text { Ratio (bee } \\
\text { bread/pollen) }\end{array}$ & & $\left(\mathrm{mg} \cdot \mathrm{kg}^{-1}\right)$ & $\begin{array}{c}\text { Ratio (bee } \\
\text { bread/pollen) }\end{array}$ \\
\hline Honey & 0.059 & - & & 0.107 & - & & 0.023 & - \\
Pollen & 0.250 & - & & 0.12 & - & & 0.009 & - \\
Bee bread & 1.929 & 7.68 & & 23.6 & 196.7 & & 3.055 & 338.9 \\
\hline
\end{tabular}

substance were used (penetration coefficient $-\rho)$. Such a calculated penetration coefficient for methyl tiophanate/iprodione in honey was 2.524 (table $I$ ) and in pollen was 11.65 (table IV), meaning that methyl tiophanate penetrates more readily into honey and pollen than iprodione. But in bee bread there is a different situation. The penetration coefficient for iprodione is lower than 1 as are the penetration coefficients for tiophanate/vinclozolin in all bee products: 0.28 for honey, 0.34 for pollen and 0.021 for bee bread. This means that vinclozolin penetrates more readily into bee products than methyl tiophanate - the systemic one.
Despite a declared contact mode of action, both iprodione and vinclozolin were transported between plant organs (table $\mathrm{V}$ ). After 5 days up to $0.14 \%$ of both fungicides applied to the old leaves were found in young leaves and flowers.

All pesticides undergo decomposition in plant tissues. Although honey is not a living tissue, it contains active enzymes that change honey composition during storage. Also, pesticide residues decompose in stored honey. Thrasyvalou [13] has found that fluvalinate breaks down in honey within about 24 weeks, while bromopropylate persists 
Table IV. Recalculated contamination of pollen collected during blooming period of cherry with methyl tiophanate, vinclozolin and iprodione.

\begin{tabular}{|c|c|c|c|c|c|c|}
\hline \multirow[t]{2}{*}{ Date } & Cherry pollen & \multicolumn{3}{|c|}{ Fungicide $\left(\mathrm{mg} \cdot \mathrm{kg}^{-1}\right)_{\mathrm{M}}$} & \multirow{2}{*}{$\begin{array}{c}\rho \\
(\text { tioph/vinc })\end{array}$} & \multirow{2}{*}{$\begin{array}{c}\rho \\
\text { (tioph/ipr) }\end{array}$} \\
\hline & $(\%)$ & Methyl tioph. & Vinclozolin & Iprodione & & \\
\hline 30 April & 4.6 & 0.1136 & & 0.0265 & & 0.98 \\
\hline 1 May & - & - & & - & & - \\
\hline 2 May & 24.9 & 1.1947 & & 0.1178 & & 2.36 \\
\hline 3 May & - & - & & - & & - \\
\hline 4 May & - & - & & - & & - \\
\hline 5 May & 36.0 & 0.1436 & 0.2871 & 0 & 0.36 & \\
\hline 6 May & 78.6 & 0.0650 & 0.1426 & 0 & 0.42 & \\
\hline 7 May & 75.8 & 0.0361 & 0.1335 & 0 & 0.25 & \\
\hline 8 May & 94.0 & 0.3175 & 0.0671 & 0 & 0.44 & \\
\hline 9 May & 46.1 & 1.0008 & 1.5184 & 0.0572 & 0.11 & 17.49 \\
\hline 10 May & 39.1 & 0.2679 & 0.4499 & 0.0259 & 0.2 & 10.34 \\
\hline 11 May & 61.0 & 0.2288 & 0.4133 & 0.0174 & 0.53 & 13.15 \\
\hline 12 May & 61.9 & 0.0889 & 0.4891 & 0.0132 & 0.16 & 6.73 \\
\hline 13 May & 75.5 & 0.0602 & 0.3134 & 0.0057 & 0.17 & 10.56 \\
\hline 14 May & & & 0.1189 & 0.0026 & & \\
\hline Average & 53.8 & $0.319 \pm 0.332$ & $0.3933 \pm 0.4227$ & $0.0332 \pm 0.0381$ & 0.34 & 11.65 \\
\hline
\end{tabular}

Table V. Transport of vinclozolin and iprodione in cherry plant shoots.

\begin{tabular}{lccc}
\hline Organs treated or analysed & \multicolumn{2}{c}{ Fungicide $\left(\mathbf{m g} \cdot \mathrm{kg}^{-1}\right)$} & $\rho$ \\
\cline { 2 - 3 } & Iprodione & Vinclozolin & (ipr/vincl) \\
\hline Treated, old leaves & 2484 & 587.0 & 4.29 \\
Untreated, young leaves & 0.982 & 0.390 & 2.44 \\
Flowers & 3.532 & 0.424 & 8.25 \\
\hline
\end{tabular}

for over 9 months, malation for 75-95 days, amitraz about 4 weeks, oxytatracycline for 6-10 weeks but cumaphos does not appear to degrade at all.

Figure 2 presents results of an experiment on persistence of methyl tiophanate, vinclozolin and iprodione in honey. As seen, the rate and course of decay of methyl tiophanate and iprodione are similar. Decomposition of these substances proceeds systematically - time of half-decay is about 4-6 months. But for vinclozolin the pattern is entirely different! During the first months of storage instead of decrease, a distinct increase of contamination occurs, followed by a subsequent decay!

\section{DISCUSSION}

It was found previously [5] that honey collected from strawberry flowers sprayed with procymidone ('Sumilex') and dichlofluanid ('Euparen') is less contaminated than pollen. Similarly, it was found [12] that radioactive contamination of honey, as a result of the Chernobyl accident, was much lower than contamination of pollen. Thus, it seems that nectaries are more effectively protected against contamination with contact fungicides than pollen grains in anthers.

Protection of the cherry plantation against fungal diseases during the blooming period also resulted in contamination of bee prod- 
ucts - honey, pollen and bee bread - with fungicides used. Similarly as in strawberries, contamination of honey with fungicides used was low. But contamination of pollen was also low (table III). However, bee bread was very heavily contaminated, from 32 time higher than honey for methyl tiophanate to 220 times higher for vinclozolin, and 132 times higher for iprodione (the ratio product/honey on the basis of data from table $I I I)$.

Recovery rate of standards was similar for pollen and bee bread, but distribution of standard in pollen grains after fortification was probably different than distribution of naturally accumulated pesticide residues. Practically, standards used for fortification remain on the outer surface of pollen grains, whereas systemic pesticides transported to the pollen grains via the vascular system are most likely located inside the grains. Some authors claim that membranes of pollen grains are very resistant and some of them, for example of dandelion (Taraxacum), remain undigested in the alimentary canal of bees [10]. However, prolonged extraction with organic solvents did not result in increased amounts of pesticides detected and organic solvents used for extraction are known to destroy lipid membranes. Thus, though incomplete extraction of pesticide residues from pollen cannot be totally excluded, it is not very likely.

Another possible explanation of this phenomenon is that pesticide residues in pollen grains are covalently conjugated. Such a conjugate could not be extracted with the organic solvent used or, even if extracted, it would have different chromatographic properties and could not be identified as a pesticide. During fermentation of bee bread the conjugate could be broken down and free pesticide released. Some support for this hypothesis comes from another surprising result - the increase in vinclozolin residue in stored honey (figure 2). Since honey was stored in closed containers without any contact with pesticides, the source of this increase must have been internal. Reversible conjugation of pesticide is the only logical explanation of this phenomenon.

Vinclozolin and iprodione are regarded as contact fungicides $[2,11]$. Thus, one should expect that the highest contamination of pollen with those pesticides would be just after spray and then steadily decreasing. However, in our experiments the dynamics

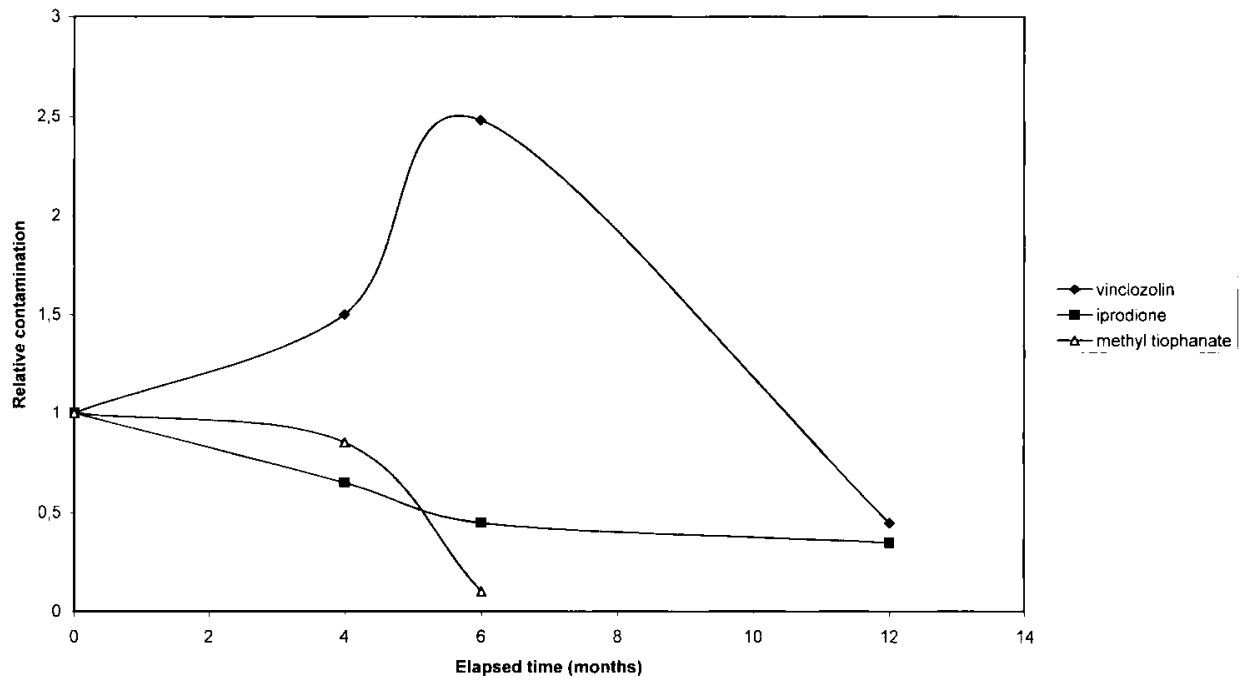

Figure 2. Changes in residues of fungicides during storage of cherry honey. 
of pollen contamination with those pesticides was similar to dynamics of contamination with systemic fungicide - methyl tiophanate, i.e. there was a 4-5-day lag period observed between spraying of the cherry plants and the occurrence of maximum contamination of pollen (figure 1 ). This time is needed for penetration and transportation of active substance of fungicides from deposition place (leaves, petals or stems) to the young anthers where formation and maturation of pollen grains occurs. Transport of the active ingredient from sprayed organs to pollen grains is especially visible after the first application of a mixture of methyl tiophanate and iprodione (29 April). Since at that time no flower buds were opened yet, direct contamination of anthers was impossible. Therefore, the only source of contaminants found in pollen 3-4 days later was transport of fungicides from another part of the plant. After the second spray (5 May) with a mixture of three preparations methyl tiophanate (systemic), vinclozolin and iprodione - plants were at full bloom, thus anthers could be contaminated directly. However, also at that time the course of pollen contamination was the same for all of them, with similar lag periods. This suggests that direct contamination of pollen is negligible and the majority of contaminants detected in pollen grains were transported there. The reason for the lack of direct contamination of pollen may be the lack of mature open anthers during evening spraying. Probably all mature pollen was collected by bees during the day and during evening sprays pesticides were deposited on the surface of immature, unopened anthers. On the following days bees harvested uncontaminated pollen from freshly opened anthers, until pollen grains became contaminated as a result of transport of fungicides from other parts of the plants. A similar lag period between application of the systemic insecticides to the soil and appearance of maximum contamination of nectar was observed in fuchsia, nasturtium and broad bean [7].
Systemic properties of vinclozolin were confirmed in an experiment where vinclozolin and iprodione applied to old leaves were transported to young leaves and flowers (table $V$ ).

One practical conclusion can be drawn from the presented work: great attention must be paid to the determination of residues of pesticides in pollen. Pesticide residues may be present in conjugated form difficult to detect with standard procedures, which may result in a gross underestimation of contamination.

\section{ACKNOWLEDGEMENT}

This work was financially supported by KBN grant 0221/S3/94/06.

Résumé - Les résidus de pesticides dans les produits de la ruche récoltés sur des cerisiers traités pendant la floraison avec des fongicides systémiques et de contact. Cinq colonies d'abeilles (Apis mellifera L.), saines et fortes, ont été transférées dans des ruches vides ne renfermant que des hausses et des feuilles de cire gaufrée et placées, avant la floraison, au milieu d'un verger de cerisiers (Prunus cerasus cv English morello) de 4,5 ha. La plantation a reçu une pulvérisation d'un mélange de thiophanate-méthyl (Topsin $\mathbf{M}^{\circledR}$ ) et d'iprodione (Rovral 50WP ${ }^{\circledast}$ ) juste avant le début de la floraison. Lors de la pleine floraison, la plantation a été à nouveau traitée avec un mélange de thiophanate-méthyl, d'iprodione et de vinchlozoline (Ronilan $50 \mathrm{WP}^{\circledR}$ ). Le pollen a été récolté tous les jours à l'aide d'une trappe à pollen, le miel et le pain d'abeilles à la fin de la floraison.

Une analyse pollinique a été effectuée sur tous les échantillons de miel, de pollen et de pain d'abeilles et les résidus de pesticides analysés par chromatographie en phase gazeuse pour l'iprodione et la vinchlozoline et par chromatographie haute pression pour le thiophanate-méthyl.

La contamination du miel a généralement été faible $\left(0,02\right.$ à $\left.0,1 \mathrm{mg} \cdot \mathrm{kg}^{-1}\right)$, le produit le 
plus contaminé étant le pain d'abeilles ( 1,9 à $23,6 \mathrm{mg} \cdot \mathrm{kg}^{-1}$ ). Les résidus de fongicides dans les pelotes de pollen ont été étonnamment faibles comparés aux résidus dans le pain d'abeilles : environ 200 fois moins pour le vinchlozoline et 300 fois moins pour l'iprodione, bien que le pain d'abeilles ait comporté $50 \%$ de pollen de cerisier (tableau III). L'explication la plus vraisemblable est de supposer que les résidus de pesticides sont présents dans les grains de pollen sous forme liée de sorte qu'ils ne peuvent être extraits par les solvants organiques ou, s'ils sont solubilisés, ne peuvent être détectés sous cette forme par la méthode utilisée. À la suite de la fermentation du pollen lors de la fabrication du pain d'abeilles, les molécules de la substance active sont libérées et l'on peut alors mesurer la contamination réelle du pollen. La liaison réversible du pesticide avec le substrat peut expliquer aussi un autre résultat inattendu : l'augmentation de la teneur en vinchlozoline au cours du stockage du miel.

Les fongicides vinchlozoline et iprodione, appliqués sur les vieilles feuilles, ont été retrouvés sur les jeunes feuilles et sur les fleurs. Donc, bien que les fabricants annoncent un mode d'action par contact, ces pesticides se comportent comme des systémiques. Les propriétés systémiques peuvent aussi expliquer le décalage de quatre à cinq jours entre le traitement et l'apparition du pic de contamination du pollen.

D'après les résultats obtenus, nous pouvons conclure de façon générale que :

- les fongicides systémiques pénètrent plus facilement dans les produits du rucher ;

- le coefficient de pénétration de ces substances est supérieur à 1 ;

- le délai observé entre le moment du traitement et l'accumulation des pesticides dans le pollen récolté quotidiennement résulte du temps nécessaire au transport des substances actives dans une autre partie de la plante ; - on explique l'hypothèse de la plus grande contamination du pain d'abeilles par rapport aux pelotes de pollen par le fait que les particules de fongicide se lient dans les grains de pollen jusqu'à épuisement du liant ; - tout pollen provenant d'une plantation traitée avec des fongicides durant la floraison doit être soigneusement analysé quant aux résidus, car il peut être la source d'une contamination importante des produits ultérieurs. (C) Inra/DIB/AGIB/Elsevier, Paris

\section{miel / pollen / contamination / fongicide / résidu}

Zusammenfassung - Pestizidrückstände in Bienenprodukten aus während der Blüte mit Kontakt- und systemischen Fungiziden behandelten Kirschbäumen. Fünf gesunde, starke Bienenvölker wurden in leere Beuten mit Mittelwänden und Leerrahmen umgesetzt und vor der Blüte in die Mitte eines 4,5 ha grossen Kirschbaumfeldes (Prunus cerasus) gestellt. Die Pflanzung wurde kurz vor Blühbeginn mit einer Mischung aus Methyltiophanat (Topsin M) und Iprodion (Rovral $50 \mathrm{WP}$ ) gesprüht. Eine 2. Sprühung mit Methyltiophanat, Iprodion und Vinclozolin (Ronilan 50 WP) erfolgte während der vollen Blüte. Pollen wurde täglich mit Pollenfallen gesammelt, Honig und Bienenbrot wurde erst nach Ende der Blüte geerntet.

Bei all Proben, bei Honig, Pollen und Bienenbrot, wurden Pollenanalysen durchgeführt, die Fungizidbelastung wurde mit einem GC (Gaschromatographen, Iprodion und Vinclozolin) oder HPLC (Hochdruckflüssigchromatograph, Methyltiophanat) bestimmt. Die Belastung des Honigs war im allgemeinen niedrig - von 0,02 bis $0,1 \mathrm{mg} \cdot \mathrm{kg}^{-1}$ - und das am höchsten belastete Bienenbrot lag bei $1.9-23,6 \mathrm{mg} \cdot \mathrm{kg}^{-1}$. Die Belastung der Pollenhöschen war erstaunlich gering im Vergleich zum Bienenbrot - sie lag für Vinclozolin 200 und bei Iprodion 300 mal niedriger, obwohl das Bienenbrot zu $50 \%$ aus Kirschpollen bestand (Tabelle III). die vernünftigste Erklärung dafür ist die Annahme, da $\beta$ die Pestizidrückstände in den Pollenhöschen in einer gebundenen Form vorliegen, so da $\beta$ sie nicht mit den organischen Lösungsmitteln extrahiert wer- 
den konnten, oder, falls sie doch gelöst wurden, in dieser Form nicht mit den angewandten Methoden nachweisbar waren. Nach der Fermentation der Pollen zur Erzeugung des Bienenbrots werden die aktiven Substanzen frei und die wirkliche Kontamination des Pollen könnte so gemessen werden. Die reversible Bindung der Pestizide könnte auch ein anderes unerwartetes Ergebnis erklären, den Anstieg des Vinclozolingehalts während der Lagerung im Honig.

Vinclozolin und Iprodion, die nur auf alte Blätter aufgetragen wurde, konnten in jungen Blättern und Blüten nachgewiesen werden. Demnach haben die Pestizide auch systemischen Eigenschaften, obwohl sie vom Hersteller als Kontaktmittel bezeichnet werden. Diese systemischen Eigenschaften könnten auch die 4-5 Tage Verzögerungsspanne zwischen Sprühen und der höchsten Kontamination des Pollen erklären. Insgesamt können auf Grund der Ergebnisse folgende Schlüsse gezogen werden:

- Systemische Fungizide gelangen leichter in Bienenprodukte;

- Der Koeffizient für das Eindringen liegt bei diesen Substanzen über 1, eine zeitliche Verzögerung bei der Akkumulation im Pollen wird beobachtet und wahrscheinlich wird ein Teil des Fungizids an Metabolite der Pflanzen gebunden;

- Die zeitliche Verzögerung, die bei der Akkumulation von systemischen Pestiziden in täglich gesammelten Pollen beobachtet wird, ist wohl auf die Zeit zurückzuführen, die für den Transport der aktiven Substanzen innerhalb der Pflanze nötig ist;

- Als hypothetische Erklärung für die viel stärkere Kontamination von Bienenbrot als von Pollenhöschen wird angenommen, dass die Pollenkörner Partikel des Fungizids binden, bis es keine Bindungskomponenten mehr gibt;

- Pollen, der von während der Blüte gespritzten Pflanzungen stammt, sollte immer gründlich auf seine Belastung untersucht werden, denn er könnte eine Quelle für die Kontamination von Folgeprodukten sein. (C) Inra/DIB/AGIB/Elsevier, Paris

Honig / Pollen / Kontamination / Rückstände / Fungizide

\section{REFERENCES}

11] Haouar M.L., de Cormis R.J., Le fluvalinate appliqué sur pommiers en pleine floraison: contamination des abeilles butineuses et des produits de la ruche, Agronomie 2 (1990) 133-137.

12] Hartley D., Kidd H., The Agrochemicals Handbook, The Royal Society of Chemistry, The University of Nottingham, UK, 1983.

13] Jaycox E.R., Effect on honcybees of nectar from systemic insecticide (reated plants, J. Econ. Entomol. 57 ( 1964 ) 31-35.

14] Kubik M., Pidek A., Goszczyñski W., Nowacki J. Michalczuk L., Can 'Sumilex' applied to the raspberry plantation be the source of contamination of bee honey, Fruit Sci. Rep. 18 (1991) $119-124$.

[5] Kubik M., Pidek A., Nowacki J., Warakomska Z., Michalczuk L., Pesticide residues in pollen and bee-honey collected from strawberry plantation protected with fungicides 'Sumilex' and 'Euparen', Fruit Sci. Rep. 19 (1992) 63-72.

[6] Kubik M., Nowacki J., Pidek A., Warakomska Z., Michalczuk L.. Goszczyñski W.. Contamination of bee-products collected from black currant (Ribes nigra hort.) plantation protected during blooming period with contact and systemic pesticides, Pszcz. Zesz. Nauk. 41 (1997) 167-175.

17] Lord K.A., May M.A., Stevenson J.H., The secretion of the systemic insecticides dimethoate and phorate into nectar, Ann. Appl. Biol. 61 (1968) 19-27.

18] Maurizio A.. Schenker P.. Ist Nektar nach Behandlung der Pflanzen mit Etilon und Diazinon gifting fur Bienen?, Schweiz. Entomol. Ges. 26 (1953) 305-309.

19] McGregor S.E., Insect pollination of cultivated crop plants, Agriculture handbook No. 496. Agriculture Research Service US Dept. of Agric., Washington, 1976, pp. 208-209.

[10] Penny Y.S., Albert S., Magnoni V., Jusup K., The digestion of dandelion pollen by adult worker honeyhees, Physiol. Entomol. 10 (1985) 75-82.

111] Róźañski L., Vadenecum Pestycydów, AgraEnviro Lab., Poznañ, 1996.

[12] Skiba T., Ignaciuk K., Radioactive contamination of hive products harvested in Poland in 1986. Pszczel. Zesz. Nauk. 31 (1987) 91-105 (in Polish).

[13] Thrasyvoulou A., Residues of insecticides (acaricides) in honey: how dangerous are they and ways to reduce them. Melissokomiki- Epithorisi 6 ( 1992 ) 296-302 (in Greek). 